\title{
Accounting Issues: An Essay Series Part I - Introduction To Accounting Theory And Cash
}

\author{
Judy Laux, (Email: coloradocollege.edu), Colorado College
}

\begin{abstract}
Recent accounting scandals challenge academics to refocus the educational process on the theoretical underpinnings of accounting. This is the first in a series of articles designed to facilitate this realignment. Intended as a supplement for the introductory accounting course, the essay series connects each of the primary accounting elements to the essential theoretical constructs, discusses the inherent tradeoffs and measurement dilemmas involved, describes newsworthy examples of "accounting gone bad," and offers a brief bibliography for further investigation should students (or professors) choose to research the element in more depth. Accounting instructors may elect to include the entire series if time permits or may select articles committed only to certain topics; each essay is designed to stand independently, with only the current article as required preparation.
\end{abstract}

\section{INTRODUCTION}

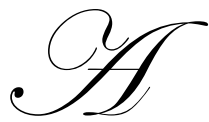

$s$ accounting educators, we have lost sight of the objectives of accounting information, at least at the introductory accounting level. We have been so driven to teach mechanics, computer applications, and pseudo discussion/case study scenarios that we now omit the very knowledge base required for students to develop the mental acuity requisite for sound accounting practice in life after principles of accounting. ${ }^{1}$ The accounting profession currently calls this "new" way of thinking principles- (or objectives-) based standard setting. Seasoned accounting professors recognize its links to the conceptual framework, including the objectives of accounting information and the hierarchy of qualitative characteristics. This series invites academics to revisit and their students to explore (perhaps for the first time) the fundamental concepts and investigate how they relate to each of the major accounting elements. To that end, the next section offers further justification for this exercise and is followed by a brief introduction to the most critical theoretical building blocks. Finally, the conceptual framework is applied to the first of the accounting elements, Cash.

\section{WHY THIS SERIES?}

Recent scandals — whether the result of fraud or "GAAP-challenged" accounting-provide ample evidence that accounting statements often do not reflect the underlying economics of many business events. To allocate resources most efficiently, market participants must be able to rely on reported accounting information, and recognition of this fact has led to both legislation (Sarbanes-Oxley) and to a new discussion of objectives-based versus rules-based accounting. ${ }^{2}$ To encourage students and educators to become sufficiently informed about the difference in these two approaches to setting accounting standards requires knowledge and discussion of the conceptual framework - a theoretical chapter once found in introductory texts but removed due to cost and time constraints. It is now time to reintroduce these theoretical building blocks at the principles level, to encourage a better way of teaching and learning accounting, cultivating improved thinking that would lead more naturally to a principles-based product as students become practicing accountants.

\footnotetext{
${ }^{1}$ See Amernic and Craig [2004] for a good discourse on this need.

${ }^{2}$ For elaboration on this point, see SEC [2003], Choi and McCarthy [2003], and Linn and Diehl [2005].
} 
What we lack is a good set of "teaching essays" that allows us to introduce students to the essential theories and unanswered questions associated with assets, liabilities, stockholders' equity, revenues, and expenses. These essays should challenge students to link theoretical issues with economic events and GAAP representation of those events. Introductory textbooks offer the occasional vignette to encourage students to think about the theory behind GAAP and the places where accounting challenges appear (e.g., recognizing revenues, selecting depreciation inputs, and valuing intangibles), but nowhere is there a comprehensive guide to the special issues surrounding each accounting element. This series of brief essays bridges the gap. To engage students, each offers a conversational tone, is independent (relying only on the theoretical portion of this first introductory article), and is written at a level appropriate for students in the introductory financial accounting course. The following section summarizes the essential theoretical background.

\section{THE CONCEPTUAL FRAMEWORK AT A GLANCE ${ }^{3}$}

Introductory texts generally offer satisfactory coverage of the objectives of accounting information-to provide useful financial information about a firm's economic resources, claims to those resources, and changes in them. This information should be understandable and helpful to investors and creditors in assessing future cash flows. The hikers among you might relate well to the following analogy. If the goal is to reach the summit, the mountaintop represents the "why" of accounting. When, over time, revenues increase and/or expenses decrease and net income increases, statement readers should be safe in surmising a more promising future for the cash flows to a firm. In addition, its asset base relative to its liabilities should also be improving, since stockholders' equity increases.

On the way to the summit (providing useful information), we must ascend the foothills. In accounting theory terms, these include the qualitative characteristics and accounting elements. The two primary qualitative characteristics are relevance and reliability, and while each has a number of underlying features, suffice it to say that, for information to be useful to investors and creditors, it must be received in time to be relevant to the decision at hand - it must make a difference, either in terms of offering feedback on a previous economic decision or helping to predict the economic effects of current decisions. Secondly, the information must possess reliability-we can trust that it can be verified, represents a fair quantitative measure of the event being reported, and is not intended to make the investor or creditor react favorably (or unfavorably). Finally, two supporting qualities make information more useful to decision makers - comparability and consistency. The first refers to the decision maker's ability to look at the financial statements of two different firms with the belief that information was measured and reported in a similar fashion, resulting in numbers that make equal economic events, in fact, look equal. The second gives the statement reader assurance that, when confronted with GAAP-approved choices among accounting methods, accountants choose one and stick with it from period to period (unless they clearly disclose that a change has been sanctified). Thus appraising economic events over time becomes possible.

Also in the foothills, the accounting elements provide the mechanical/categorical basis for most of what the principles of accounting course addresses. We begin with assets, typically first provided by investments by owners or borrowing from creditors (creation of liabilities) and later increased through earning revenues. These assets can be decreased by distributions to owners or through incurrence of expenses. Gains and losses show up in the disposition of property, plant, and equipment, relatively late in the course. Finally, the excess of revenues (and gains) over expenses (and losses) results in the net income ("comprehensive income") of the firm and serves to increase stockholders' equity. These elements provide the building blocks for most of what accounting does.

\footnotetext{
${ }^{3}$ The following section relies on both FASB [1980] and Kieso [2003, pp. 28-39]. The mountain hiking analogy used in this series is displayed on the following page with relevant items bolded in the text.
} 


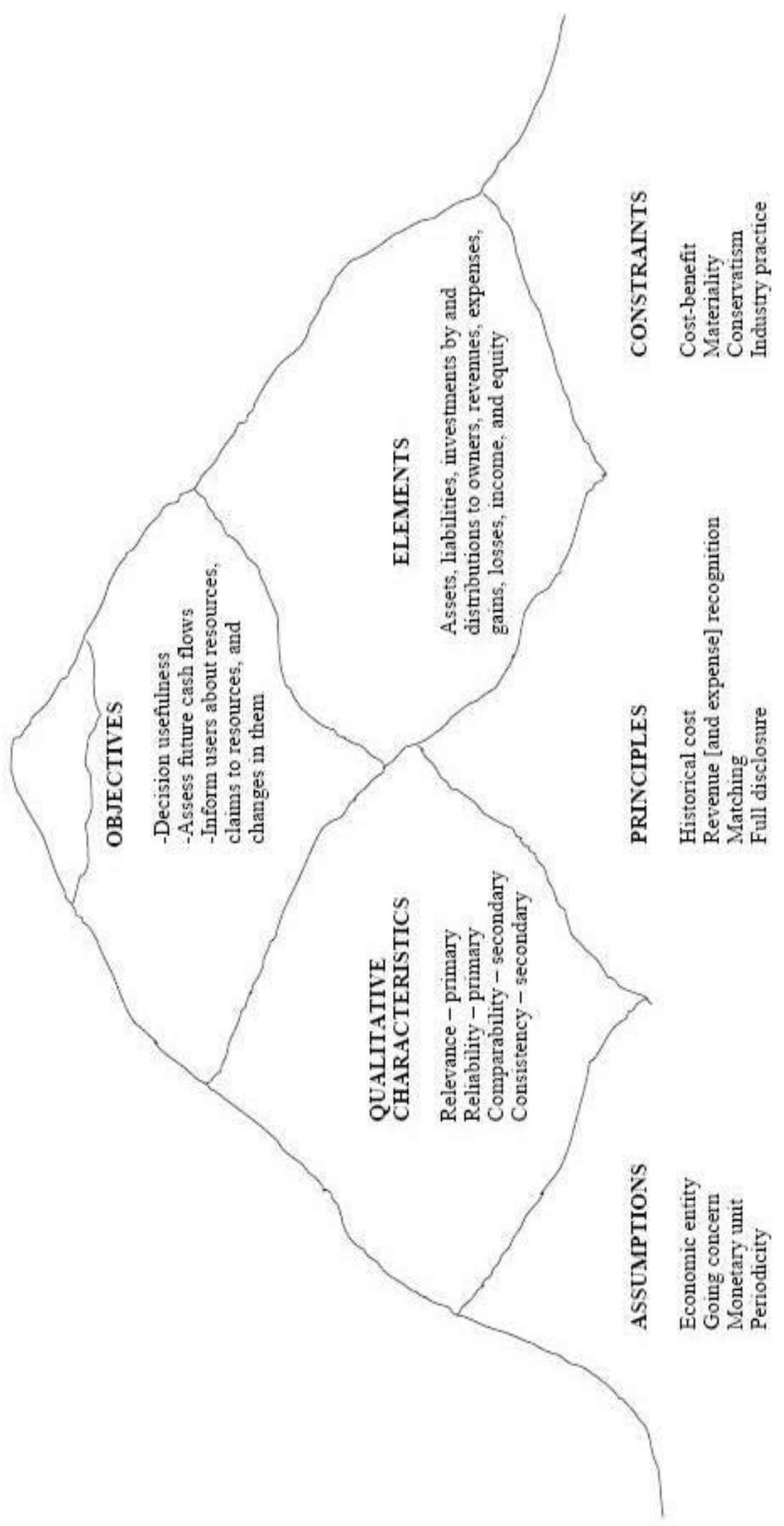


The journey up the mountain begins "in the trenches," on the plains of everyday bookkeeping. This is the "how" of accounting, in Kieso's terminology. As they begin the ascent from the plains, accountants are often unaware that even these gentle slopes can be slippery. These are the places in everyday accounting that can make or break that successful ascent to the peak. These early steps can be taken firmly, with both compass and conviction. Or they can be stealthy and misdirected, skirting the trailhead and leading to false summits far from the mountaintop destination. This part of our metaphorical climb consists of accounting assumptions, principles, and constraints. These help determine which economic events will be recognized in the accounting system as well as when and how they will be measured. The assumptions (economic entity, going concern, monetary unit, and periodicity), principles (historical cost, revenue - and expense - recognition, matching, and full disclosure), and constraints (cost-benefit, materiality, conservatism, and industry practice) are introduced throughout the first accounting course. As we cover each major element in this essay series, those most applicable to that particular element will be addressed, especially as they relate to the challenges accountants face (including the relevance-reliability tradeoff and measurement dilemmas). This process begins as the next section applies these theoretical concepts to a central asset, Cash.

\section{THE CONCEPTUAL FRAMEWORK AND CASH}

Due to the nature of cash, it represents perhaps the only accounting item that possesses high degrees of relevance, reliability, verifiability, and comparability. Few would argue that the amount of cash offers relevance for statement readers, as it helps in judging a firm's capacity to pay bills, take advantage of special purchasing opportunities, and reduce risks associated with illiquidity. Measured at current value, cash poses few measurement issues, with the exception that the definition of "cash equivalents" requires management discretion regarding classification of such items as T-bills, commercial paper, and money market funds. Still, these cash equivalents can be audited easily and verified, along with actual bank balances, ensuring a certain level of reliability. Full disclosure requires that footnotes clearly identify the make-up of the cash balance, enhancing understandability and comparability. Materiality can play a role, requiring special attention to classification of items (such as compensating balances) that have a cash "feel" but actually place restrictions on the firm's ability to use the cash. Separate disclosure is required, and the SEC has actually defined materiality (a rarity) as 15\% of liquid assets. Finally, reconciling the cash account with the bank statement at the end of an accounting period forces firms to adhere to the matching principle (whereby expenses are matched with revenues in the period in which they are incurred to generate those revenues) and, hence, the periodicity assumption.

Though in many ways analyzing the theoretical connections is easiest for cash, cash control can be a major time-consumer for firms, which go to great lengths to establish control procedures to prevent theft of this asset. The next section highlights moments in history when cash has made the headlines and also offers a brief bibliography of articles related to accounting for cash.

\section{CASH IN THE LITERATURE}

Much of the literature devoted to the topic of cash addresses control issues surrounding that easily pocketed asset. That is, the amount reported in the financial statements is not usually in question; it's what happens before that ultimate reconciliation that receives the bulk of the attention. Some of the statistics are unsettling:

- $\quad$ According to estimates, a third of American workers have stolen on the job. [Wells, 2001]

- $\quad$ Skimming [stealing cash before its entry into the formal accounting system] is by far the most popular method for stealing an organization's cash. (By incidence: Skimming sales, 64.2\%; receivables, 25.3\%; refunds/other, $10.5 \%$.) [Wells, 2002]

- $\quad$ Cash is the asset most often stolen by dishonest employees. [Buckhoff et al, 2003]

- $\quad$ Research indicates that about $92 \%$ of all asset theft fraud schemes involve cash, with median losses of $\$ 65,000$ per incident. [Buckhoff, 2004]

- $\quad$ A 2003 KPMG survey found that $75 \%$ of respondents had experienced at least one instance of employee theft, a 13\% increase over its 1998 survey. [Kramer and Buckhoff, 2005]

- $\quad$ The Association of Certified Fraud Examiners estimated in 2002 that fraud costs organizations about $\$ 600$ billion per year, or about $6 \%$ of total revenues. [Kramer and Buckhoff, 2005] 
- A 2003 PricewaterhouseCoopers survey projected the average fraud loss per company at $\$ 2.2$ million, with $60 \%$ of the losses resulting from employee theft. [Kramer and Buckhoff, 2005]

- $\quad$ According to fraud experts, about $40 \%$ of fraudulent activity goes undetected. [Kramer and Buckhoff, 2005]

What makes cash such a favorite target? "Cash is fungible, has a specific value, and is easily transported." [Wells, 2001] As such, it is especially subject to skimming (as defined above), fraud (in particular, through fraudulent disbursements), and occasionally, larceny (theft after formal entry into the accounting system). ${ }^{4}$

Recipes for spotting fraud and preventing opportunities for theft abound in the literature. For especially good, brief synopses and examples of the recommended detective process for uncovering abuses, see Hall [1996], Wells [2001, 2002], Buckhoff et al [2003], Buckhoff [2004], and Kramer and Buckhoff [2005]. In summary, however, because existing cash balances are exceptionally auditable, cash disclosure on the balance sheet is viewed as generally reliable.

\section{THIS SERIES CONTINUES}

This article has provided the basis for a series of brief articles that connects the theoretical constructs of the conceptual framework to the various accounting elements. It has offered insights into the first of the accounting assets, Cash, and invited readers to look at a few approachable articles addressing the measurement and control issues surrounding that important account. The next in the series will look at the prime concerns accountants face as they measure and report accounts receivable, one of the more popular sources of accounting scandals in recent years.

\section{REFERENCES}

1. Amernic, Joel and Russell Craig. 2004. Reform of Accounting Education in the Post-Enron Era: Moving Accounting 'Out of the Shadows." Abacus. Vol. 40, No. 3: 342-378.

2. Buckhoff, Thomas. 2004. Cash: The Favorite Target of Fraudsters. CPA Journal. Vol. 74, Issue 11: 63.

3. Buckhoff, Thomas, James Clifton, and Robert H. Colson. 2003. Exotic Embezzling: Investigating Off-Book Fraud Schemes. CPA Journal. Vol. 73, Issue 9, 56-58.

4. Choi, Yeong C. and Irene N. McCarthy. 2003. FASB Proposes Principles-Based Approach to US Standards Setting. Bank Accounting \& Finance. Vol. 16, Issue 9: 5-11.

5. Financial Accounting Standards Board. 1980. Qualitative Characteristics of Accounting Information. Statement of Financial Accounting Concepts No. 2. Stamford, Conn.

6. Hall, John J. 1996. How to Spot Fraud. Journal of Accountancy, Vol. 182, Issue 4: 85-88.

7. Kieso, Donald E., Jerry J. Weygandt, and Terry D. Warfield. 2003. Fundamentals of Intermediate Accounting. United States: John Wiley \& Sons, Inc.

8. Kramer, Bonita K. Peterson and Thomas A. Buckhoff. 2005. Catching Fraudsters with Their Hands in the Till. CPA Journal. Vol. 75, Issue 5: 13-15.

9. Linn, Erik and Kori Diehl. 2005. Financial Restatements: Causes, Consequences, and Corrections. Strategic Finance. Vol. 87, Issue 3: 35-39.

10. Securities and Exchange Commission. 2003. Study Pursuant to Section 108(d) of the Sarbanes-Oxley Act of 2002 on the Adoption by the United States Financial Reporting System of a Principles-Based Accounting System. Available online at http://www.sec.gov/news/studies/principlesbasedstand.htm.

11. Wells, Joseph T. 2001. Enemies Within. Journal of Accountancy. Vol. 192, Issue 6: 31-35.

12. 2002. ....And One for Me. Journal of Accountancy. Vol. 193, Issue 1: 90-92.

${ }^{4}$ For elaboration on each of these points, see Wells, 2001. 


\section{NOTES}

